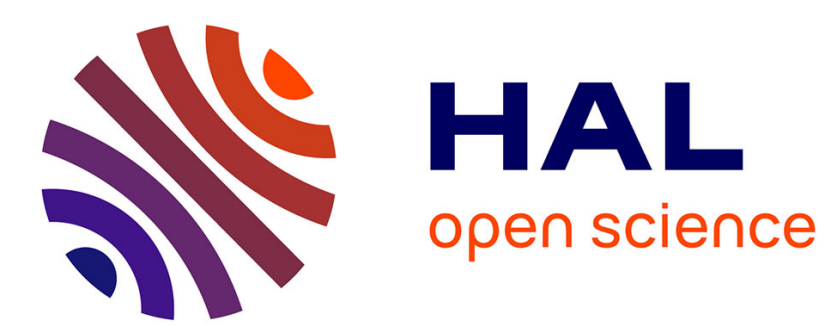

\title{
HALL EFFECT IN KONDO ALLOYS CeCu5-xAlx
}

\author{
A. Hamzic, A. Fert, Jean-Marc Broto, M. Miljak, E. Bauer, E. Gratz
}

\section{To cite this version:}

A. Hamzic, A. Fert, Jean-Marc Broto, M. Miljak, E. Bauer, et al.. HALL EFFECT IN KONDO ALLOYS CeCu5-xAlx. Journal de Physique Colloques, 1988, 49 (C8), pp.C8-777-C8-778. 10.1051/jphyscol:19888351 . jpa-00228533

\section{HAL Id: jpa-00228533 https://hal.science/jpa-00228533}

Submitted on 1 Jan 1988

HAL is a multi-disciplinary open access archive for the deposit and dissemination of scientific research documents, whether they are published or not. The documents may come from teaching and research institutions in France or abroad, or from public or private research centers.
L'archive ouverte pluridisciplinaire HAL, est destinée au dépôt et à la diffusion de documents scientifiques de niveau recherche, publiés ou non, émanant des établissements d'enseignement et de recherche français ou étrangers, des laboratoires publics ou privés. 


\title{
HALL EFFECT IN KONDO ALLOYS $\mathrm{CeCu}_{5-\boldsymbol{x}} \mathrm{Al}_{\boldsymbol{x}}$
}

\author{
A. Hamzic $\left({ }^{1}\right)^{1}$ A. Fert $\left({ }^{1}\right)$, J. M. Broto $\left({ }^{1}\right)$, M. Miljak $\left({ }^{2}\right)$, E. Bauer $\left({ }^{3}\right)$ and E. Gratz $\left({ }^{3}\right)$ \\ $\left({ }^{1}\right)$ Laboratoire de Physique des Solides, Université Paris Sud, F-91405 Orsay, France \\ $\left.{ }^{2}\right)$ Institute of Physics, POB 304, 41001 Zagreb, Yugoslavia \\ $\left.{ }^{3}\right)$ Institute of Experimental Physics, T.U. Vienna, Austria
}

\begin{abstract}
We present Hall effect measurements on disordered Kondo alloys $\mathrm{CeCu}_{5-x} \mathrm{Al}_{x}(x=1$ and $x=2)$. Our results at low temperatures cannot be accounted for by only skew scattering terms and support the existence of an additional contribution from anomalous velocity effects.
\end{abstract}

The $\mathrm{CeCu}_{5-x} \mathrm{Al}_{x}$ alloy series includes heavy fermion (HF) system such as $\mathrm{CeCu}_{4} \mathrm{Al}$ and $\mathrm{CeCu}_{3} \mathrm{Al}_{2}$ in which the temperature coefficient of the electronics specific heat respectively amounts to about $1.5 \mathrm{~J} / \mathrm{mol} \mathrm{K}^{2}$ and $0.5 \mathrm{~J} / \mathrm{mol} \mathrm{K}^{2}[1]$. However, in contrast with the case of classical HF compounds, the disordered substitution of $\mathrm{Al}$ for $\mathrm{Cu}$ prevents the development of coherence effects at low temperatures and the behavior of the $\mathrm{CeCu}_{4} \mathrm{Al}$ and $\mathrm{CeCu}_{3} \mathrm{Al}_{2}$ alloys is that of a collection of independent Kondo impurities. This is shown in figure 1 by the continuous increase of the resistivity for decreasing temperatures.

In this communication, we present Hall effect measurements on $\mathrm{CeCu}_{4} \mathrm{Al}$ and $\mathrm{CuCu}_{3} \mathrm{Al}_{2}$ alloys. The large anomalous Hall effect of the HF systems is generally ascribed to skew scattering and interpreted in the existing single impurity skew scattering models $[2,3]$. As shown recently, anomalous velocity contributions could also be significant below the Kondo temperature [6]. In ordered compounds such as $\mathrm{CeAl}_{3}$ [4], $\mathrm{CeCu}_{6}$ [5], $\mathrm{UPt}_{3}$ [4], etc..., the single impurity skew scattering models accounts fairly well for the experimental data at high and intermediate temperatures and very poorly at low temperatures. But it is hard to establish whether this discrepancy arises from the onset of coherence effects - not taken into account in the models or from the onset of anomalous velocity contributions. The $\mathrm{CeCu}_{5-x} \mathrm{Al}_{x}$ alloys - without coherence effects are of interest to shed some light on this problem.

Figures 2 and 3 display the temperature dependence of the initial Hall constant for $\mathrm{CeCu}_{4} \mathrm{Al}$ and $\mathrm{CeCu}_{3} \mathrm{Al}_{2}$ respectively. We do not find the usual behavior of coherent HF compounds in which $R_{\mathrm{H}}$ presents a pronounced maximum at about the onset temperature for coherence and drops rapidly at lower temperatures. This can be understood from the expression [3]:

$$
R_{\mathrm{H}}=R_{\mathrm{H}}^{\mathrm{ord}}+\gamma \tilde{\chi} \rho
$$

where $R_{\mathrm{H}}^{\text {ord }}$ is the ordinary Hall constant, $\gamma \tilde{\chi} \rho$ is the skew scattering contribution, $\tilde{\chi}$ is the reduced suscep-

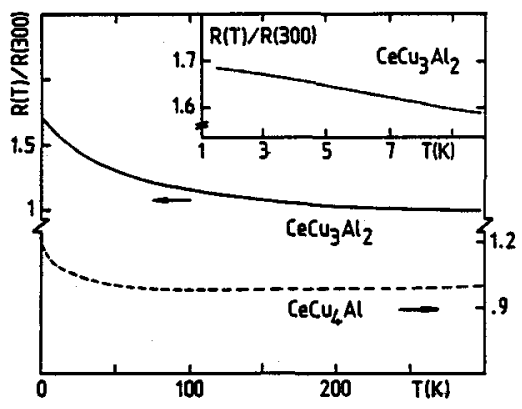

Fig. 1. - Resistivity vs. temperature for $\mathrm{CeCu}_{4} \mathrm{Al}$ and $\mathrm{CeCu}_{3} \mathrm{Al}_{2}$.

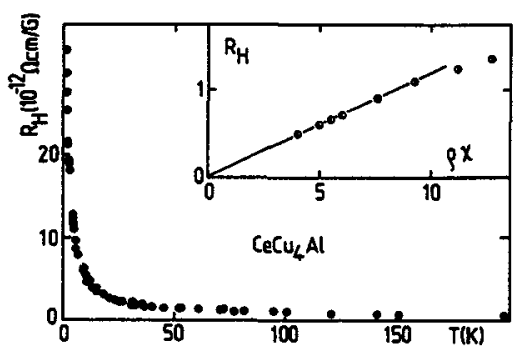

Fig. 2. - Initial Hall constant vs. temperature for $\mathrm{CeCu}_{4} \mathrm{Al}$. Inset: determination of the ordinary Hall constant from the high temperature data. We find $R_{\mathrm{H}}^{\text {ord }} \approx 0$.

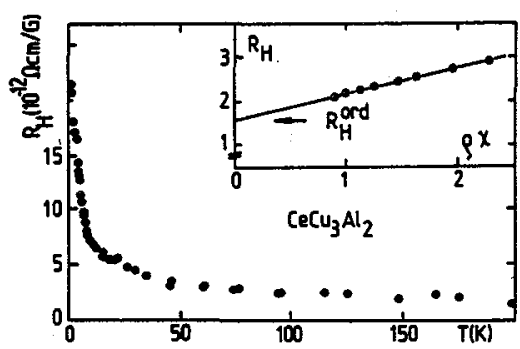

Fig. 3. - Initial Hall constant vs. temperatures for $\mathrm{CeCu}_{3} \mathrm{Al}_{2}$. Inset: Determination of $R_{\mathrm{H}}^{\text {ord }}$ from the high temperature data. We find: $R_{\mathrm{H}}^{\text {ord }} \approx 1.55 \times 10^{-12} \Omega \mathrm{cm} / \mathrm{G}$.

\footnotetext{
${ }^{1}$ Permanent address: Department of Physics, University of Zagreb, BP 162, Zagreb, Yugoslavia.
} 
tibility (i.e. susceptibility over Curie constant) and $\rho$ is the magnetic resistivity. In our $\mathrm{CeCu}_{5-x} \mathrm{Al}_{x}$ alloys not only $\chi$ but also $\rho$ continue to increase down to $1 \mathrm{~K}$, so that $R_{\mathrm{H}}$ is not expected to present the low temperature drop of the coherent compounds. This has also been found in other incoherent systems [7-9]. To test equation (1) we assume a temperature independent value of $R_{\mathrm{H}}^{\text {ord }}$ (derived as shown in the inset of Fig. 2 and 3 ) and we plot the ratio $r=\left(R_{\mathrm{H}}-R_{H}^{\text {ord }}\right) / \chi \rho$ as a function of $T$ in figure 4 and 5 . Down to about $20 \mathrm{~K}$, for both $\mathrm{CeCu}_{4} \mathrm{Al}$ and $\mathrm{CeCu}_{3} \mathrm{Al}_{2}$, the ratio $r$ is approximately temperature independent, which is in agreement with equation (1) and an approximately constant value of

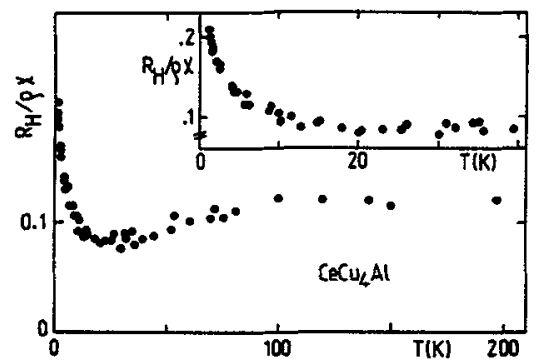

Fig. 4. $-\left(R_{\mathrm{H}}-R_{\mathrm{H}}^{\text {ord }}\right) / \rho \chi$ vs. temperature for $\mathrm{CeCu}_{4} \mathrm{Al}$ $\left(\mathrm{R}_{\mathrm{H}}^{\text {ord }} \approx 0\right.$ for $\mathrm{CeCu}_{4} \mathrm{Al} ; \rho$ and $\chi$ measured on the same sample).

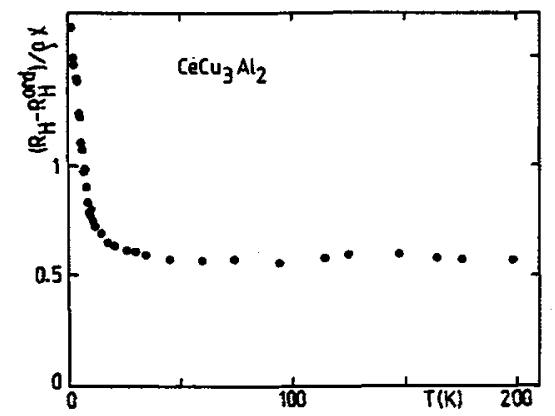

Fig. 5. $-\left(R_{\mathrm{H}}-R_{\mathrm{H}}^{\text {ord }}\right) / \rho \chi \quad$ vs. temperature for $\mathrm{CeCu}_{3} \mathrm{Al}_{2}\left(R_{\mathrm{H}}^{\text {ord }} \approx 1.55 \times 10^{-12} \Omega \mathrm{cm} / \mathrm{G} ; \rho\right.$ and $\chi$ measured on the same sample). the coefficient $\gamma$ [10]. Below about $20 \mathrm{~K}$, in both systems, the ratio $r$ increases steeply. This enhancement of the Hall effect appears too strong to be merely explained by a change of the relatively small ordinary Hall effect or by impurity effects. As a matter of fact, we have also found systematic similar enhancements in other incoherent $\mathrm{HF}$ systems $\left(\mathrm{Ce}_{1-x} \mathrm{La}_{x} \mathrm{Cu}_{6}\right.$ [8], irradiated $\left.\mathrm{CeCu}_{2} \mathrm{Si}_{2}[9], \ldots\right)$. Such enhancements can be due to a change of the coefficient of the skew scattering term $\gamma$ below the Kondo temperature $T_{\mathrm{K}}(\gamma$ is expected to change by $T_{\mathrm{K}}$ ) or by the onset of an anomalous velocity contribution below $T_{\mathrm{K}}$. As $\gamma$ is expected to change very progressively around $T_{\mathrm{K}}[11]$, we rather believe that the experimental data of figure 4 and 5 indicate the existence of anomalous velocity contributions to the Hall effect of HF systems at low temperatures.

[1] Bauer, E., Gignoux, D., Schmitt, D. and Winzer, K., J. Magn. Magn. Mater. 69 (1987) 158.

[2] Coleman, P., Anderson, P. W. and Ramakrishnan, T. V., Phys. Rev. Lett. 55 (1985) 414.

[3] Fert, A. and Levy, P. M., Phys. Rev. B 36 (1987) 1907.

[4] Lapierre, F., Haen, P., Briggs, R., Hamzic, A., Fert, A. and Kappler, J. P., J. Magn. Magn. Mater. 63-64 (1987) 338.

[5] Penney, T., Milliken, F. P., von Molnar, S., Holtzberg, F. and Fisk, Z., Phys. Rev. B 34 (1986) 5959.

[6] Levy, P. M., Guo, Wei, Fert, A. and Cox, D. L., this Conf.

[7] Fert, A., Pureur, P., Hamzic, A. and Kappler, J. P., Phys. Rev. B 32 (1985) 7003.

[8] Onuki, Y. and Kamatsubara, T., J. Magn. Magn. Mater. 63-64 (1987) 281.

[9] Adrian, G. and Adrian, H., Physica 148B (1987) 26.

[10] In $\mathrm{CeCu}_{4} \mathrm{Al}$ the ratio $r$ decreases by about $30 \%$ between $100 \mathrm{~K}$ and $20 \mathrm{~K}$. This could reflect a decrease of the prefactor $\gamma$ at the approach of the Kondo temperature.

[11] Levy, P. M., Guo, Wei and Cox, D. L., to be published. 